DOI: https://doi.org/10.47405/mjssh.v5i12.591

\begin{tabular}{|c|c|}
\hline$x=$ & Malaysian Journal of Social Sciences and Humanities (MJSSH) \\
\hline Malaysian Journal of & Volume 5, Issue 12, December 2020 \\
\hline (MJ-ssH) & e-ISSN : 2504-8562 \\
\hline & $\begin{array}{l}\text { Journal home page: } \\
\text { www.msocialsciences.com }\end{array}$ \\
\hline
\end{tabular}

\title{
Kefahaman dan Tingkah Laku Masyarakat Terhadap Amalan Filantropi Islam Semasa Pandemik COVID-19
}

\author{
Umi Hamidaton Mohd Soffian Lee' ${ }^{1}$, Abdul Rashid Abdul Aziz'², Asma Md. Isa ${ }^{3}$ \\ ${ }^{1}$ Fakulti Ekonomi dan Muamalat, Universiti Sains Islam Malaysia (USIM) \\ ${ }^{2}$ Fakulti Kepimpinan dan Pengurusan, Universiti Sains Islam Malaysia (USIM) \\ ${ }^{3}$ Fakulti Sains Sosial dan Kemanusiaan, Universiti Kebangsaan Malaysia (UKM)
}

Correspondence: Abdul Rashid Abdul Aziz (rashid@usim.edu.my)

\begin{abstract}
Abstrak
Wabak COVID-19 yang melanda Malaysia telah memberikan implikasi yang amat besar kepada rakyat. Hal ini kerana, ia telah menyebabkan pelbagai perubahan dalam sistem politik, ekonomi, sosial, kesihatan, dan pendidikan negara. Bahkan, wabak yang berlaku juga menyebabkan individu kehilangan kerja dan punca pendapatan, pelajar-pelajar miskin ketinggalan dalam pelajaran disebabkan oleh pengenalan kepada sistem pembelajaran secara online, masalah kesihatan mental yang semakin meruncing dan banyak lagi. Amalan filantropi dilihat amatlah signifikan dalam keadaan semasa ini bagi meningkatkan sosio-ekonomi masyarakat, mengurangkan kadar kemiskinan dan membantu mengurangkan kadar pengangguran dalam masyarakat. Justeru, kajian ini bertujuan untuk menilai tahap kefahaman masyarakat terhadap amalan filantropi serta menilai tahap kesediaan dan penglibatan masyarakat melalui sikap dan tingkah laku terhadap amalan filantropi semasa wabak COVID-19. Kajian ini menggunakan metod kuantitatif dengan reka bentuk kajian rentas terhadap 250 orang responden beragama Islam yang bekerja. Perisian Statistical Package for Social Sciences (SPSS) digunakan dalam menganalisis data. Hasil kajian mendapati bahawa responden menunjukkan tahap kefahaman yang positif terhadap amalan filantropi (nilai min antara 3.89 hingga 4.61). Responden juga dilihat menunjukkan tahap kesediaan dan penglibatan masyarakat dalam amalan filantropi yang tinggi apabila min bagi setiap konstruk yang mengukur objektif ini berada pada nilai 4.0 dan ke atas. Kajian ini dilihat amat signifikan dalam mengurangkan kadar kemiskinan dan jurang ekonomi yang wujud dalam masyarakat Malaysia. Ia dapat menjadi sumber rujukan dan panduan bagi badan kerajaan atau bukan kerajaan dalam membentuk sesuatu polisi baru serta merangka ekonomi Malaysia.
\end{abstract}

Kata Kunci: filantropi, COVID-19, kedermawanan

\section{Understanding and Behavior of Society to The Practice of Islamic Philantrophy During COVID-19 Pandemics}

\begin{abstract}
COVID-19 outbreak which strike Malaysia has huge implications for the citizen. It has caused various changes in the political, economic, social, health, and education systems of the country. In fact, the outbreak also caused individuals to lose their jobs and sources of income, poor students lagging behind in education due to the introduction to online learning systems, escalating mental health problems and more. The practice of philanthropy is seen as a very significant in the current situation to improve the socio-economy of society, reduce poverty and help to reduce unemployment in society. Thus, this
\end{abstract}


study aims to assess the level of public understanding of philanthropy practices as well as assess the level of readiness and involvement of the community through attitudes and behaviors towards philanthropic practices during COVID-19 outbreak. This study uses a quantitative method of cross sectional study design of 250 working Muslim respondents. Statistical Package for Social Sciences (SPSS) software is used in analyzing the data. The results of the study found that the respondents showed a positive level of understanding of the practice of philanthropy (mean value between 3.89 to 4.61). Respondents were also seen to show a high level of community readiness and involvement in philanthropic practice when the mean for each construct measuring this objective was at a value of 4.0 and above. This study is very significant in reducing the poverty rate and economic gap that exists in Malaysian society. It can be a source of reference and guidance for government or non-government bodies in formulating a new policy in Malaysian economy.

Keywords: philanthropy, COVID-19, generosity

Kerajaan telah melancarkan Wawasan Kemakmuran Bersama 2030 bermatlamat untuk menjadikan Malaysia sebagai salah sebuah negara yang membangun melalui pengagihan ekonomi yang adil, saksama dan inklusif tanpa mengira latar belakang dan asal-usul seseorang. Ia melibatkan elemen pengukuhan hubungan dalam kalangan masyarakat untuk saling membantu dan bersatu padu sebagai asas penyatuan negara bangsa melalui pemahaman, peranan dan tingkah laku yang ditonjolkan oleh setiap individu di negara ini. Tambahan pula, pada ketika ini seluruh masyarakat Malaysia masih berdepan dengan cabaran dan ancaman wabak COVID-19.

Saban hari kita menyaksikan pertambahan angka kematian dan kes jangkitan aktif COVID-19 diseluruh pelusuk dunia yang membuktikan kita masih bertarung untuk bebas sepenuhnya dari cengkaman wabak ini. Menurut laporan daripada Pertubuhan Kesihatan Sedunia (World Health Organisation, WHO) sehingga 30 November 2020, jumlah kes COVID-19 mencecah 62 juta dengan lebih dari 1.4 juta kematian diseluruh dunia. Di Malaysia pula, jumlah kes positif telah mencapai angka 65,697 dan kematian sebanyak 360 orang (Laporan Statistik Kementerian Kesihatan Malaysia, 2020) sekali gus wabak yang melanda Malaysia ini telah memberi kesan yang sangat besar kepada sistem politik, ekonomi, sosial, kesihatan dan pendidikan negara. Justeru, pelbagai inisiatif kawalan telah dilaksanakan secara berperingkat melalui beberapa mekanisme yang telah diperkenalkan oleh pihak kerajaan, swasta dan masyarakat. Secara kronologinya, wabak Coronavirus atau COVID-19 telah diisytiharkan sebagai pandemik global oleh WHO pada 12 Mac 2020 setelah ia mula tersebar dengan begitu cepat hingga mengakibatkan 196 buah negara dijangkiti termasuk Malaysia (Cucinotta \& Vanelli, 2020; Berita Harian, 2020; Hadil, Fatimah \& Reem, 2020).

Perintah Kawalan Pergerakan (PKP) atau Movement Control Order (MCO) telah bermula pada 18 Mac 2020 secara berperingkat bagi mengekang penularan wabak COVID-19 terutama melibatkan masyarakat setempat (Perutusan Khas Perdana Menteri, 2020). PKP di negara ini telah dijalankan secara strategik dan sistematik berpandukan kitaran pengurusan krisis mengikut piawaian antarabangsa (International Organization for Standardization) atau ISO (Pursiainen, 2020). Keberhasilan usaha yang dilaksanakan oleh kerajaan bergantung kepada tahap kepekaan, kefahaman dan kesediaan setiap lapisan masyarakat mematuhi saranan, garis panduan dan SOP (standard operation procedure) melalui amalan norma baru seharian (Hadil, Fatimah \& Reem 2020).

Berdasarkan statistik yang dikeluarkan oleh Laporan Tinjauan Tenaga Buruh (2020), adalah dijangkakan dalam tempoh yang singkat hampir 2.4 juta pekerja di negara ini akan hilang punca pendapatan. Bahkan berlaku peningkatan kadar pengangguran sebanyak 3.9 peratus sehingga bulan Mac 2020 berbanding 3.3 peratus pada tahun sebelumnya (Jabatan Perangkaan Malaysia, 2020). Berikutan senario dan kemelut yang melanda ini,elemen filantropi atau kedermawanan dilihat mampu memainkan peranan yang tersendiri. Hal ini kerana, filantropi adalah amalan kebaikan yang dilakukan seseorang berdasarkan rasa sayang dan cinta kepada orang lain. Ia membawa kepada kesediaan dan kesanggupan seseorang untuk membantu orang lain dengan memberi sumbangan dalam pelbagai bentuk secara sukarela tanpa sebarang paksaan. Malah, filantropi dalam Islam mengandungi pelbagai 
instrumen yang mempunyai tatacara dan fungsi tertentu yang membawa kebaikan dalam kehidupan. Ini kerana, filantropi merangkumi sumbangan dan pemberian sedekah, wakaf, zakat dan hibah yang merujuk kepada tingkah laku dermawan oleh individu, organisasi atau institusi merangkumi masa, wang, tenaga secara ikhlas tanpa sebarang paksaan (Abdul Hasbi, 2018). Amalan filantropi dalam Islam bertujuan untuk memenuhi semua tuntutan kehidupan melalui sikap tolong menolong tatkala orang lain ditimpa musibah. Amalan ini juga telah diamalkan oleh masyarakat sejak ribuan tahun dahulu (Razali, 2017).

Objektif dan matlamat yang dituntut dalam amalan filantropi Islam adalah selari dengan keperluan semasa untuk masyarakat bersama-sama berganding bahu menghulurkan bantuan dan sumbangan dalam pelbagai bentuk termasuk wang ringgit dan bukan harta benda kepada golongan yang terkesan terutama akibat bencana COVID-19. Selain itu, amalan filantropi ini juga merupakan amalan kebaikan yang dilakukan kepada setiap makhluk dengan niat untuk mendekatkan diri kepada Allah SWT. Amalan kedermawanan ini tidak hanya melibatkan mereka yang mampu secara ekonomi tetapi turut melibatkan masyarakat secara keseluruhan dengan rasa penuh tanggungjawab untuk meringankan beban orang lain.

Oleh itu, kajian berkaitan tahap kefahaman dan tahap penglibatan melalui sikap dan tingkah laku dalam amalan filantropi melibatkan masyarakat semasa COVID-19 amat penting sebagai kayu ukur untuk membuktikan sejauh mana kefahaman, kesediaan dan penglibatan masyarakat dalam menunaikan apa yang dituntut oleh Allah SWT. Terdapat dua tujuan utama kajian ini dilaksanakan. Pertama, untuk menilai tahap kefahaman masyarakat terhadap amalan filantropi. Kedua, untuk menilai tahap kesediaan dan penglibatan masyarakat melalui sikap dan tingkah laku terhadap amalan filantropi semasa wabak COVID-19. Kajian ini dilihat signifikan kerana amalan kedermawanan merupakan satu indikator penting dalam ajaran Islam tentang kepedulian dan keadilan sosial yang dapat dipraktikkan oleh individu dalam masyarakat demi kebaikan semua (Razali, 2017).

\section{Sorotan Literatur}

\section{Konsep Filantropi dari Perspektif Islam dan Barat}

Menurut Abdullah Alqari et al. (2018) dan Razali (2017), perkataan filantrofi berasal dari gabungan dua suku kata bahasa Greek iaitu phil (cinta) dan anthropos (manusia). Gabungan kedua-dua suku kata ini memberi maksud cinta atau sayang kepada manusia. Secara dasarnya, filantropi merupakan konsep yang berkait rapat dengan tindakan dan tingkah laku yang menjurus kepada kebaikan, kasih sayang, belas kasihan, kemurahan hati dan rasa cinta kepada manusia. Perasaan kasih dan sayang yang wujud terhadap orang lain mencetuskan tingkah laku untuk terlibat secara langsung dalam amalan filantropi sehingga sanggup menyumbangkan harta miliknya demi membantu orang lain. Justeru itu, amalan filantropi yang disarankan oleh ajaran Islam memainkan peranan penting dalam pembangunan sosioekonomi masyarakat kerana ia merupakan salah satu bentuk instrumen pengalihan pendapatan orang kaya kepada orang miskin melalui peranan elemen-elemen filantropi (Aris Puji \& Muchlis, 2018). Dalam amalan seharian, filantropi boleh disama-ertikan sebagai kedermawanan, sementara individu yang sering kali berbuat baik dengan memberi bantuan dan pertolongan kepada orang lain dikenali sebagai dermawan.

Seterusnya, dalam surah al-Kahfi ayat 30, filantropi didefinisikan sebagai salah satu bentuk kebaikan yang hakiki (al birr). Ini adalah kerana amalan kedermawanan merupakan salah satu bentuk ajaran Islam tentang kepentingan mekanisme yang mendorong kewujudan keadilan sosial dan rasa kepedulian sesama manusia. Antara amal soleh yang amat disukai Allah SWT apabila hambanya berlumba-lumba membelanjakan harta kekayaan untuk kebaikan mereka yang memerlukan seperti anak yatim, fakir miskin dan orang-orang yang berada dalam kesusahan dan memerlukan pertolongan (Razali, 2017; Wan Mohd Yusof et al., 2018).

Menurut Oxford Dictionary of Current English dan Thohari (2017), filantropi merujuk kepada love of mankind; practical sympathy and benevolence iaitu dalam Bahasa Melayu dapat ditakrifkan sebagai 
DOI: https://doi.org/10.47405/mjssh.v5i12.591

cinta terhadap manusia, rasa simpati dan kebajikan. Barat telah menjadikan filantropi sebagai salah satu instrumen penting dalam sistem ekonomi moden kerana ia dijadikan alternatif untuk menangani isu melibatkan ketidakadilan agihan sosio-ekonomi akibat dominasi doktrin kapitalisme (Wan Mohd Yusof et al., 2018). Pelaksanaan dan konsep filantropi barat berbeza dengan amalan filantropi Islam kerana ia memfokuskan kepada amalan sukarelawan sebaliknya filantropi Islam melibatkan amal kebajikan dan amal jariah untuk mendekatkan diri dengan Allah SWT.

Namun begitu terdapat beberapa penekanan yang telah dibuat oleh para pengkaji tentang konsep filantropi. Ilchman (2006) menekankan elemen dorongan rasa kecintaan kepada manusia akan menggerakkan seseorang untuk menderma. Sebaliknya, Klien (2001) lebih menekankan sikap sukarela berbanding rasa cinta untuk mendorong amalan filantropi. Seterusnya, Payton (1988) melihat filantropi sebagai tingkah laku sukarela yang dapat menyumbang kepada manfaat dan kebaikan umum. Oleh itu, melalui definisi-definisi yang diberikan menunjukkan bahawa skop filantropi tidak hanya terbatas kepada pemberian material semata-mata tetapi ia turut melibatkan aktiviti sukarelawan yang dilakukan atas dorongan kasih sayang dan tanggungjawab.

Sejarah filantropi Islam telah bermula sejak zaman Nabi Muhammad SAW apabila baginda membelanjakan 100 dirham untuk membeli tanah bagi tujuan pembinaan masjid Quba dan masjid tersebut diwakafkan untuk digunakan oleh seluruh umat Islam hingga ke hari ini. Selain daripada itu, melalui kajian awal yang telah dijalankan terhadap pelaksanaan salah satu elemen filantropi Islam iaitu zakat telah menunjukkan bahawa ia telah disyariatkan oleh Allah SWT kepada para nabi dan Rasul sepertimana yang telah dilaksanakan oleh Nabi Ibrahim, Nabi Ismail, Nabi Musa dan Nabi Isa. Malahan, zakat telah ditetapkan sebagai satu kewajipan mutlak dan rukun Islam untuk dilaksanakan (Anwar, 2014).

Sebaliknya, dari sudut perspektif Barat konsep filantropi adalah sinonim dengan konsep charity namun Steve Gunderson (Presiden \& CEO Council of Foundation) menyangkal kenyataan ini dengan menyatakan bahawa "charity tends to be a short-term, emotional, immediate response, focused primarily on rescue and relief, whereas philantrophy is much more long-term, more stratergic, focused on rebuilding". Filantropi merupakan salah satu kaedah yang berperanan bukan sahaja untuk membantu malahan mencari akar kepada masalah yang wujud serta berusaha untuk mencari jalan keluar. Filantropi menawarkan penyelesaian terbaik kepada masalah yang timbul dalam kalangan masyarakat seperti mana bencana yang berlaku dan memberi impak tertentu kepada masyarakat secara amnya (Abdullah Alqari et al., 2018).

Walaupun secara asasnya konsep dan amalan filantropi Islam dilihat daripada bawaan Barat namun Islam tetap mempunyai konsep dan amalan filantropinya yang tersendiri (Razali, 2017). Dalam konteks Islam, filantropi telah menghubungkan seluruh umat Islam melalui peranan yang dilakukan atas dasar keimanan dan peranan kemasyarakatan sebagai salah tanggungjawab kepada Allah SWT (Alterman \& Hunter, 2004). Ia lebih terarah kepada membangunkan aspek keadilan sosial dalam tempoh jangka panjang misalnya melalui wakaf. Filantropi telah mengatur hubungan manusia dengan Allah (habluminallah) dan memelihara hubungan manusia dengan manusia (habluminanas). Ia harus dilakukan secara baik, benar dan seimbang agar mendapat manfaat di dunia dan akhirat. Nilai-nilai murni ini akan mendasari amalan filantropi seperti mana yang disarankan dalam al-Quran dan hadith. Melalui penelitian yang telah dijalankan, filantropi Barat lebih tertumpu kepada dorongan rasa kemanusiaan sebaliknya Islam tertumpu kepada dorongan untuk mencari keredhaan Allah SWT. Oleh itu, filantropi ialah wacana khas untuk membolehkan seseorang atau sesebuah institusi memberi sumbangan bagi tujuan memakmurkan masyarakat dari sudut agama, nyawa, akal keturunan dan kelestarian alam.

\section{Kajian tentang Amalan Filantropi}

Sebagai salah sebuah negara yang mempunyai majoriti penduduk beragama Islam, amalan kedermawanan telah menjadi perkara biasa dalam kalangan masyarakat di Malaysia. Malahan, impak positif penglibatan dalam amalan ini telah dinyatakan dalam al-Quran dan hadith. Allah SWT telah berfirman dalam surah al-Baqarah ayat 261 maksudnya: 


\begin{abstract}
"Perumpamaan (derma) orang yang membelanjakan harta benda mereka di jalan Allah, adalah sama seperti sebiji benih yang menumbuhkan tujuh tangkai, setiap tangkai itu pula mengandungi seratus biji. Dan Allah akan melipatgandakan pahala bagi sesiapa yang Dia mahu dan Allah Maha Luas Kurnia-Nya, lagi Maha mengetahui."
\end{abstract}

Berdasarkan ayat ini dapat disimpulkan bahawa perbuatan filantropi seperti memberi dan menderma akan mendatangkan kesan yang berlipat kali ganda kepada orang yang memberi dan menerima. Sehubungan itu, amalan kedermawanan yang melibatkan individu perlu diberikan penekanan kerana berdasarkan Model Amal (Charity Model) oleh Mohanty menunjukkan pelaksanaannya membawa kesejahteraan kepada masyarakat. Model ini dibangunkan berdasarkan fungsi kesejahteraan sosial oleh Arrow \& Sen yang menyatakan bahawa amalan kedermawanan yang dilaksanakan tidak akan mengurangkan jumlah kekayaan seseorang malahan akan memberi impak positif kepada yang terlibat (Salwa, Fidlizan, Joni \& Mohamad Taqiuddin, 2015). Kesan pelaksanaan kerja amal akan membantu mengisi jurang peranan dan bebanan kerajaan bagi menangani masalah sosial dan bencana alam.

Setakat ini terdapat beberapa kajian yang telah dijalankan berkaitan tingkah laku dan amalan filantropi dalam kalangan rakyat Malaysia (Salwa et al., 2015). Namun demikian, penyelidikan di Barat berkaitan amalan filantropi telah bermula sejak 1980-an untuk mengungkap rasional di sebalik fenomena pemberian amal yang berlaku. Rene dan Pamala (2011) telah mengumpulkan 500 artikel jurnal mengenai pemberian amal melalui kajian-kajian empirikal yang telah dijalankan. Di peringkat antarabangsa pemberian amal yang melibatkan filantropi telah menjadi sumber kewangan utama di negara-negara maju misalnya kajian yang dijalankan terhadap enam buah negara pada tahun 2012 telah mencatatkan kutipan sumbangan sebanyak USD 12.49 bilion, 46 peratus daripada keseluruhan sumbangan yang diperoleh daripada individu (Lilly Family School of Philanthropy, 2013). Hasil sumbangan tersebut telah disalurkan kepada yayasan untuk tujuan dan kegunaan awam, institusi pengajian tinggi, badan kesenian dan kebudayaan, kemanusiaan, keagamaan dan kesihatan.

Kajian yang dijalankan oleh Opoku (2013), mendapati bahawa faktor intrinsik dan ekstrinsik seperti agama dan kepuasan diri mendorong masyarakat di Mesir untuk terlibat dalam amalan filantropi manakala Rahmatina (2013) mendapati bahawa umat Islam di Indonesia cenderung untuk bersedekah sepertimana yang disarankan oleh agama Islam sebagai salah satu tanggungjawab yang ditekankan dalam agama. Seterusnya, di Brunei amalan filantropi dalam kalangan masyarakat disokong sepenuhnya oleh pihak kerajaan dan amalan ini menjadi sebahagian daripada kehendak agama dan budaya masyarakat di negara tersebut (Lwin et al., 2013). Di samping itu, hasil pemerhatian Cogswell (2002) mendapati amalan filantropi dalam kalangan masyarakat Malaysia berorientasikan etnik dengan menyasarkan pengumpulan dana untuk tujuan pemulihan budaya dan agama serta menangani cabaran sosio-ekonomi yang wujud.

Oleh itu, penyelidikan berkaitan amalan filantropi terutama dalam kalangan masyarakat Malaysia terutama melibatkan tahap fahaman dan amalan filantropi perlu diberi perhatian memandang kajian berkaitan bidang ini masih belum diterokai sepenuhnya (Hairunnizam et al., 2005). Kajian literatur berkaitan amalan filantropi diasaskan daripada Teori Tingkah Laku Terancang (Theory of Planned Behavior) oleh Fishbein dan Azjen $(1975 ; 1991)$. Teori ini menjelaskan dan meramalkan tentang tingkah laku seseorang untuk terlibat dalam aktiviti pemberian amal dan sukarelawan. Menurut teori ini, semakin tinggi niat seseorang untuk melakukan sesuatu amalan atau tindakan, maka semakin besar kemungkinan individu itu melaksanakan tingkah laku tersebut. Penglibatan masyarakat dilihat dapat membantu menangani kemaslahatannya yang wujud akibat pandemik COVID-19. Kajian ini disokong oleh Razali (2017), Abdiansyah (2015) yang berpendapat bahawa konsep dan amalan filantropi telah dipraktikkan sejak ribuan tahun dahulu untuk membantu kehidupan manusia tanpa mengira bangsa, agama dan kepercayaan. 


\section{Peranan Elemen Filantropi Semasa Wabak COVID-19}

Islam telah menggariskan tujuan kehidupan manusia bagi mewujudkan peranan terhadap hubungan sesama manusia dan hubungan kepada Allah serta makhluk-makhluk lain di muka bumi ini (Bakr, 2001). Asas dan keperluan membentuk hubungan sesama manusia amat relevan untuk diketengahkan kerana masyarakat kini sedang berdepan dengan ancaman wabak COVID-19. Kesaksamaan dan keadilan adalah antara prinsip utama dalam membentuk hubungan sesama manusia.

Dalam memastikan penglibatan masyarakat untuk saling membantu selain daripada peranan yang dilakukan oleh pihak kerajaan dan swasta, terdapat beberapa elemen filantropi Islam merangkumi zakat, sedekah, wakaf, infak dan hibah. Elemen-elemen ini mampu mengurangkan bebanan sosioekonomi yang dihadapi oleh sebahagian masyarakat yang terkesan akibat impak COVID-19. Kesemua elemen filantropi yang dipraktikkan ini mempunyai peranan tersendiri untuk meningkatkan sosioekonomi masyarakat, mengurangkan kadar kemiskinan dan membantu mengurangkan kadar pengangguran dalam kalangan masyarakat. Tambahan lagi, kejayaan elemen-elemen filantropi ini telah dibuktikan dan dipraktikkan semasa zaman pemerintahan Rasulullah SAW, malahan diteruskan dan diadaptasi oleh para sahabat nabi khulafa' al-Rashidun serta seterusnya dikembangkan dalam tamaduntamadun Islam terawal seperti dinasti Umayyah (41-132H), Dinasti Abassiyyah (132-656H), Dinasti Thulun (254-270H) dan Dinasti Ayubiah (569-684H) (Fauzi \& Ahmad Buchori 2020). Justeru itu, terdapat beberapa amalan filantropi seperti wakaf, zakat dan sedekah yang boleh dijadikan mekanisme tambahan untuk membantu masyarakat mengharungi krisis COVID-19.

Wakaf ditakrifkan sebagai mengapungkan harta untuk dikhususkan kegunaannya oleh pihak-pihak tertentu seperti yang dinyatakan oleh pembuat wakaf. Takrif ini disokong oleh Dr. Muhammad AlAhmad Abu Al-Nur yang menyatakan wakaf ialah harta atau hartanah yang ditahan oleh pemiliknya untuk dijual atau dibeli ataupun diberi sebagai pemberian dengan syarat digunakan, dibelanjakan dan keuntungan serta hasilnya diberikan kepada orang yang telah ditentukan (Kasim, 2020). Menurut Bahari (2017), wakaf merujuk kepada tindakan individu mengagihkan sebahagian hartanya untuk kegunaan amal. Objektif utama amalan wakaf ialah untuk mengabdikan diri kepada Allah SWT.

Wakaf merupakan antara elemen filantropi penting untuk memenuhi keperluan dan kebajikan menangani krisis ekonomi yang melanda masyarakat yang memerlukan. Dalam konteks negara Malaysia, nilai harta wakaf jika disatukan dari segi jumlah saiz dan modal keseluruhannya mencapai trillion ringgit. Oleh itu, wakaf sebenarnya berperanan untuk mengurangkan bebanan fiskal yang ditanggung negara dan isu melibatkan sosio-ekonomi masyarakat.

Selain itu, dari sudut bahasa zakat ialah bersih, suci bertambah dan berkembang. Manakala dari sudut istilah ia merujuk kepada mengeluarkan sebahagian harta tertentu kepada yang berhak dengan syaratsyarat tertentu. Zakat adalah sumbangan wajib bagi seorang Muslim untuk dibelanjakan bagi tujuan tertentu seperti mana yang telah digariskan dalam al-Quran. Pelaksanaan sistem zakat yang efisien dan sistematik adalah untuk memastikan kekayaan yang sedia ada dapat diagihkan dengan adil dan setimpal. Dalam ekonomi Islam, kekayaan tidak hanya dimonopoli oleh segelintir individu sahaja. Semasa Perintah Kawalan Pergerakan (PKP) berlangsung, Majlis Agama Islam Wilayah Persekutuan telah melancarkan kaedah bayaran zakat melalui atas talian bagi memudahkan orang ramai untuk menunaikan tanggungjawab membayar zakat. (Berita Harian, 2020).

Menurut laporan yang telah dikeluarkan oleh Lembaga Zakat Pulau Pinang, sebanyak 19 juta bantuan khas telah diperuntukkan daripada dana zakat yang diperoleh untuk membantu golongan yang terkesan akibat COVID-19. Institusi zakat merupakan badan terawal bergerak maju ke hadapan dalam membantu negara serta menyantuni masyarakat yang terjejas akibat COVID-19. Hampir 200 juta bantuan zakat melalui institusi zakat seluruh negeri telah berjaya disalurkan kepada fakir miskin, asnaf serta golongan yang terkesan dengan wabak COVID-19 (Wafdi, 2020). Melalui dana zakat yang dikutip ini telah membantu keseimbangan sosio-ekonomi dan menjamin keselamatan sosial masyarakat bagi mengharungi krisis sedia ada selari dengan kehendak agama untuk saling bantu membantu di antara satu sama lain. 
Seterusnya, sedekah merupakan perbuatan yang dilakukan dengan rela hati tanpa paksaan bagi memperoleh pahala berlipat kali ganda dari Allah SWT. Dana yang diperoleh dari amalan bersedekah ini merupakan salah satu instrumen kewangan Islam yang bersifat fleksibel dan berbentuk sukarela (Abdullah \& Muda, 2013). Ia tidak terikat dengan sesuatu kadar atau nilai tertentu sama ada berbentuk wang ringgit atau sebaliknya. Tujuan pemberian sedekah ini mampu membantu sesiapa sahaja yang berada dalam kesusahan bagi tujuan yang ditentukan.

Allah SWT telah menyarankan umat manusia untuk sentiasa bersedekah dan ganjaran bersedekah telah banyak dinyatakan dalam al Quran, misalnya dalam surah al-Mukminin ayat 60. Semasa COVID-19 amalan filantropi seperti sedekah amat digalakkan kerana menurut Razali (2017) amalan ini dapat digunakan sebagai asas pembiayaan untuk merancang, membantu dan menguruskan masyarakat yang memerlukannya. Cakna masyarakat terhadap amalan filantropi sebagai instrumen pengagihan dana bantuan secara efisien perlu dipertingkatkan dari semasa ke semasa sepanjang masyarakat dan negara berdepan dengan krisis COVID-19. Kesedaran masyarakat terhadap konsep dan penglibatan dalam amalan filantropi sebagai polisi fiskal bersifat tauhid berasaskan lebihan pendapatan dan kekayaan mampu memotivasikan seseorang untuk menceburkan diri dalam elemen filantropi.

\section{Metod Kajian}

\section{Reka Bentuk Kajian}

Kajian ini adalah kajian kuantitatif dengan menggunakan reka bentuk kajian rentas atau cross sectional study. Terdapat beberapa kelebihan menggunakan kaedah ini antaranya membenarkan pengkaji menggunakan kajian literatur filantropi dan kaedah tinjauan melalui borang soal selidik sebagai prosedur utama dalam proses mengumpulkan data kajian. Kaedah ini memberikan hasil pengumpulan data yang lebih tepat, mengelakkan unsur bias dan dapat meningkatkan kualiti data yang dikumpulkan (Cresswell, 2008: Sekaran \& Bougie, 2010).

Kajian ini dijalankan di sekitar lembah Klang, melibatkan golongan pekerja yang beragama Islam sahaja memandangkan item soal selidik memfokuskan kepada elemen filantropi Islam. Sebelum soal selidik diedarkan kepada responden, kaedah terjemahan balik telah digunakan untuk menterjemah borang soal selidik ke dalam Bahasa Melayu dan Bahasa Inggeris bagi memastikan kesahan dan kebolehpercayaan dapatan kajian diperoleh (Cresswell, 2008; Sekaran \& Bougie, 2008).

\section{Alat Pengukuran}

Borang soal selidik terdiri daripada tiga komponen utama; Pertama, demografi dan ciri-ciri responden yang terlibat. Kedua, kefahaman terhadap amalan filantropi telah diubahsuai daripada kajian literatur berkenaan kefahaman terhadap amalan filantropi (Radin, 2019). Ketiga, amalan filantropi telah diubah suai daripada kajian yang telah dijalankan oleh Bartolini (2005) dan Radin (2019). Kesemua item-item dalam borang soal selidik telah dinilai dan diukur dengan menggunakan skala likert lima (5) jawapan pilihan bermula daripada "sangat tidak setuju" (1) hingga "sangat setuju" (5). Profil demografi responden telah digunakan sebagai pemboleh ubah kawalan kerana kajian ini memfokuskan kepada persepsi individu.

\section{Kaedah Data Analisis}

Dalam kajian ini interpretasi dapatan data kajian diukur berdasarkan nilai min lima (5) skala likert (Likert Scale) berdasarkan empat tahap berikut:

Jadual 1. Min Skala Lima Likert Mengikut Empat Tahap

\begin{tabular}{ll}
\hline Nilai Min & Interpretasi \\
\hline $1.01-2.00$ & Rendah \\
$2.01-3.00$ & Sederhana Rendah \\
\hline
\end{tabular}


DOI: https://doi.org/10.47405/mjssh.v5i12.591

\begin{tabular}{ll}
\hline $3.01-4.00$ & Sederhana Tinggi \\
$4.01-5.00$ & Tinggi \\
\hline Sumber: Nunally (1978) &
\end{tabular}

\section{SampelKajian}

Bagi tujuan mendapatkan sampel responden, kajian ini menggunakan prosedur pensampelan bertujuan (purposive sampling) yang melibatkan pengedaran 250 set borang soal selidik kepada para pekerja di sekitar Lembah Klang, yang beragama Islam. Ciri-ciri asas ini amat penting untuk memastikan responden yang terlibat mempunyai pengetahuan dan kefahaman tentang amalan filantropi Islam dan berkemampuan untuk terlibat dalam amalan filantropi. Daripada jumlah keseluruhan hanya 210 atau 84 peratus borang soal selidik telah dijawab dengan lengkap dan dikembalikan kepada pengkaji. Responden yang terlibat dalam kajian ini telah menjawab soal selidik yang diedarkan dengan sukarela tanpa sebarang paksaan. Seterusnya, data-data yang diperoleh telah dianalisis dengan menggunakan Statistical Package for Social Sciences (SPSS).

\section{Profil Responden}

Dengan menggunakan statistik deskriptif didapati bahawa majoriti responden terdiri daripada perempuan (53\%), manakala lelaki (47\%). Kesemua responden yang terlibat adalah beragama Islam, telah berkahwin (75.5\%), diikuti bujang (23\%), berumur 31 tahun hingga 40 tahun (44.5\%), bekerja dalam sektor swasta (45\%), memiliki kelulusan pendidikan tertinggi pada peringkat sarjana muda (32.5\%) dan mendapat pendapatan bulanan RM3000 hingga RM3999 (21.1\%).

\section{Analisis Kebolehpercayaan Item}

Item-item yang digunakan dalam instrumen soal selidik ini telah menjalani analisis kebolehpercayaan dan Jadual 2 menunjukkan konstruk yang digunakan mempunyai nilai cronbach alfa antara 0.824 dan 0.935 yang menunjukkan konstruk-konstruk mempunyai tahap kebolehpercayaan dalaman yang tinggi. Menurut Sekaran (2003), semakin hampir nilai cronbach alfa kepada 1 semakin tinggi kebolehpercayaan item yang dibina. Nilai cronbach alfa bagi konstruk yang digunakan dalam borang soal selidik mestilah sekurang-kurangnya 0.70-0.80 ke atas, ia lebih baik (Sekaran, 2003).

Jadual 2: Kebolehpercayaan terhadap konstruk tingkah laku amalan filantrofi

\begin{tabular}{lll}
\hline Konstruk & Nilai Cronbach Alfa & Bilangan item \\
\hline Kefahaman & 0.824 & 8 \\
Tingkah Laku & 0.935 & 9 \\
\hline
\end{tabular}

\section{Hasil Kajian}

Jadual 3 di bawah menunjukkan dapatan analisis deskriptif bagi tahap kefahaman masyarakat terhadap amalan filantropi. Faktor ini menjelaskan tentang sejauh mana masyarakat faham tentang konsep amalan kedermawanan seperti mana yang disarankan oleh Islam untuk dipraktikkan dalam kehidupan seharian. Tambahan lagi untuk saling terlibat dalam aktiviti amal semasa menghadapi COVID-19.

Dapatan analisis mendapati bahawa responden telah menunjukkan tahap kefahaman yang positif terhadap amalan filantropi atau kedermawanan. Ini dapat dibuktikan berdasarkan dapatan item soal selidik yang menujukan nilai min pada tahap sederhana tinggi dan tinggi di antara 3.89 hingga 4.61. Item yang mencatatkan nilai skor paling tinggi adalah item no 4 iaitu "Kedermawanan ditakrifkan sebagai tingkah laku yang ditekankan dalam Islam” (min: 4.61). 
DOI: https://doi.org/10.47405/mjssh.v5i12.591

Diikuti dengan item no 1 iaitu "Saya akan dapat ketenangan apabila melakukan kerja amal" (min: 4.55). Seterusnya item no 8 "Sedekah adalah sumbangan yang perlu diberi dengan seikhlas hati" mencatatkan nilai (min: 4.53)". Item no 2,37,5 masing-masing mencatatkan nilai min yang tinggi antara (min: 4.48 hingga 4.10). Manakala item no 6 iaitu "Agihan zakat merupakan cara untuk membendung kemiskinan” berada pada nilai min tahap sederhana tinggi (min: 3.89).

Jadual 3: Tahap kefahaman terhadap amalan filantropi (kedermawanan)

\begin{tabular}{|c|c|c|c|c|c|c|}
\hline Pernyataan & 1 & 2 & 3 & 4 & 5 & Min \\
\hline \multicolumn{7}{|c|}{ Sejauh mana tahap kefahaman anda terhadap amalan filantropi. } \\
\hline $\begin{array}{l}\text { 1. Saya akan dapat ketenangan } \\
\text { apabila melakukan kerja amal }\end{array}$ & 0 & $\begin{array}{c}4 \\
1.9 \%\end{array}$ & $\begin{array}{c}6 \\
2.9 \%\end{array}$ & $\begin{array}{c}70 \\
33.33\end{array}$ & $\begin{array}{l}130 \\
61.9\end{array}$ & 4.55 \\
\hline $\begin{array}{l}\text { 2. Sukarelawan merupakan salah } \\
\text { satu aspek filantropi }\end{array}$ & 0 & $\begin{array}{c}2 \\
1 \%\end{array}$ & $\begin{array}{c}10 \\
4.8 \%\end{array}$ & $\begin{array}{c}84 \\
40 \%\end{array}$ & $\begin{array}{c}114 \\
54.3 \%\end{array}$ & 4.48 \\
\hline $\begin{array}{l}\text { 3. Salah satu ciri dermawan dalam } \\
\text { Islam ialah mewakafkan harta }\end{array}$ & 0 & $\begin{array}{l}3 \\
1.4 \%\end{array}$ & $\begin{array}{c}21 \\
10 \%\end{array}$ & $\begin{array}{c}89 \\
42.4 \\
\%\end{array}$ & $\begin{array}{c}97 \\
46.2 \%\end{array}$ & 4.33 \\
\hline $\begin{array}{l}\text { 4. Kedermawanan ditakrifkan } \\
\text { sebagai tingkah laku yang } \\
\text { ditekankan dalam Islam }\end{array}$ & $\begin{array}{c}1 \\
0.5 \%\end{array}$ & $\begin{array}{c}1 \\
0.5 \%\end{array}$ & $\stackrel{2}{15 \%}$ & $\begin{array}{c}70 \\
33.3 \\
\%\end{array}$ & $\begin{array}{c}136 \\
64.8 \%\end{array}$ & 4.61 \\
\hline $\begin{array}{l}\text { 5. Tolong menolong antara satu } \\
\text { sama lain merupakan ciri utama } \\
\text { kedermawanan }\end{array}$ & $\begin{array}{c}1 \\
0.5 \%\end{array}$ & $\begin{array}{c}9 \\
4.3 \%\end{array}$ & $\begin{array}{c}21 \\
10 \%\end{array}$ & $\begin{array}{c}115 \\
54.8 \\
\%\end{array}$ & $\begin{array}{c}64 \\
30.6 \%\end{array}$ & 4.10 \\
\hline $\begin{array}{l}\text { 6. Agihan zakat merupakan cara } \\
\text { untuk membendung kemiskinan }\end{array}$ & $\begin{array}{c}1 \\
0.5 \%\end{array}$ & $\begin{array}{c}15 \\
7.1 \%\end{array}$ & $\begin{array}{c}30 \\
14.3 \%\end{array}$ & $\begin{array}{r}124 \\
59 \%\end{array}$ & $\begin{array}{c}40 \\
19 \%\end{array}$ & 3.89 \\
\hline $\begin{array}{l}\text { 7. Sifat kedermawanan adalah salah } \\
\text { satu cara untuk mendekatkan diri } \\
\text { dengan Allah SWT }\end{array}$ & 0 & $\begin{array}{c}1 \\
0.5 \%\end{array}$ & $\begin{array}{c}8 \\
3.8 \%\end{array}$ & $\begin{array}{c}114 \\
54.3 \\
\%\end{array}$ & $\begin{array}{c}87 \\
41.4 \%\end{array}$ & 4.37 \\
\hline $\begin{array}{l}\text { 8. Sedekah adalah sumbangan yang } \\
\text { perlu diberi dengan seikhlas hati }\end{array}$ & 0 & 0 & $\begin{array}{c}5 \\
2.4 \%\end{array}$ & $\begin{array}{c}88 \\
41.9 \\
\%\end{array}$ & $\begin{array}{c}117 \\
55.7 \%\end{array}$ & 4.53 \\
\hline
\end{tabular}

Jadual 4 menunjukkan dapatan analisis deskriptif melibatkan skor tingkah laku masyarakat terhadap amalan filantropi. Faktor ini menjelaskan tentang tahap kesediaan individu untuk terlibat dalam amalan filantropi terutama semasa berdepan dengan situasi COVID-19 yang sedang melanda negara pada ketika ini.

Jadual 4: Sikap dan tingkah laku filantropi (kedermawanan)

\begin{tabular}{lcccccc}
\hline \multicolumn{1}{c}{ Pernyataan } & $\mathbf{1}$ & $\mathbf{2}$ & $\mathbf{3}$ & $\mathbf{4}$ & $\mathbf{5}$ & Min \\
\hline Bagi menghadapi Covid-19 saya sudi: & & & & & & \\
1. $\begin{array}{l}\text { Terlibat dalam aktiviti } \\
\text { sukarelawan }\end{array}$ & 3 & 29 & 58 & 70 & 50 & 3.64 \\
2. $\begin{array}{l}\text { Ikhlas menghulurkan } \\
\text { bantuan tanpa sebarang }\end{array}$ & $1.4 \%$ & $13.8 \%$ & $27.6 \%$ & $33.3 \%$ & $23.8 \%$ & \\
$\begin{array}{l}\text { balasan } \\
\text { Memperuntukkan harta }\end{array}$ & $0.5 \%$ & $7.1 \%$ & $5.2 \%$ & $57.1 \%$ & $10 \%$ & 3.69 \\
$\begin{array}{l}\text { untuk membantu anak yatim } \\
\text { Bersedekah menggunakan }\end{array}$ & 0 & $0.5 \%$ & $3.3 \%$ & $47.1 \%$ & $49 \%$ & 4.45 \\
$\begin{array}{l}\text { wang ringgit walaupun } \\
\text { jumlahnya sedikit }\end{array}$ & 0 & 0 & 7 & 92 & 111 & 4.50 \\
5. & & & $3.3 \%$ & $43.8 \%$ & $52.9 \%$ & \\
$\begin{array}{l}\text { Menginfaqkan harta saya } \\
\text { untuk membantu yang }\end{array}$ & 0 & $1.4 \%$ & $10.5 \%$ & $49 \%$ & $39 \%$ & 4.26 \\
\hline
\end{tabular}


Malaysian Journal of Social Sciences and Humanities (MJSSH), Volume 5, Issue 12, (page 1 - 15), 2020

DOI: https://doi.org/10.47405/mjssh.v5i12.591

\begin{tabular}{|c|c|c|c|c|c|c|c|}
\hline & $\begin{array}{l}\text { Memberi hadiah walaupun } \\
\text { harganya tidak mahal }\end{array}$ & 0 & $\begin{array}{c}3 \\
1.4 \%\end{array}$ & $\begin{array}{c}21 \\
10 \%\end{array}$ & $\begin{array}{c}97 \\
46.2 \%\end{array}$ & $\begin{array}{c}89 \\
42.4 \%\end{array}$ & 4.30 \\
\hline 7 & $\begin{array}{l}\text { Menolong orang yang } \\
\text { berada dalam kesulitan }\end{array}$ & 0 & $\begin{array}{c}1 \\
0.5 \%\end{array}$ & $\begin{array}{c}15 \\
7.1 \%\end{array}$ & $\begin{array}{c}117 \\
55.7 \%\end{array}$ & $\begin{array}{c}77 \\
36.7 \%\end{array}$ & 4.29 \\
\hline 8 & $\begin{array}{l}\text { Memberi makan kepada } \\
\text { yang kelaparan }\end{array}$ & 0 & 0 & $\begin{array}{c}5 \\
2.4 \%\end{array}$ & $\begin{array}{c}90 \\
42.9 \%\end{array}$ & $\begin{array}{c}115 \\
54.8 \%\end{array}$ & 4.52 \\
\hline 9 & Membayar zakat & 0 & 0 & $\begin{array}{c}18 \\
8.6 \%\end{array}$ & $\begin{array}{c}96 \\
45.7 \%\end{array}$ & $\begin{array}{c}96 \\
45.7 \%\end{array}$ & 4.37 \\
\hline
\end{tabular}

Berdasarkan data yang diperoleh mendapati bahawa responden telah menunjukkan tingkah laku yang tinggi dan sederhana tinggi dalam menjalankan amalan filantropi seperti yang telah disarankan. Merujuk kepada jadual berikut item yang mendapat nilai skor paling tinggi ialah item no 8 iaitu "memberi makan kepada yang kelaparan" (min: 4.52). Diikuti dengan item no 4 iaitu "bersedekah menggunakan wang ringgit walaupun jumlahnya sedikit" (min: 4.50), kemudian item no 3 "memperuntukkan harta untuk membantu anak yatim" (min: 4.45). Di samping itu item no 9, 6, 7 dan 5 turut tersenarai dalam kumpulan item yang mendapat skor min paling tinggi apabila nilai min skor di antara (min: 4.37 hingga min 4.26). Sebaliknya item yang lain seperti item no 2 dan 1 tersenarai dalam kumpulan item yang mendapat nilai skor min sederhana tinggi apabila masing-masing mencatatkan (min: 3.69) dan (min: 3.64).

\section{Perbincangan Kajian}

Dapatan kajian ini menunjukkan bahawa tahap kefahaman dan tahap tingkah laku masyarakat terhadap amalan filantropi berada pada skala yang amat memberangsangkan. Ia membuktikan bahawa masyarakat peka tentang konsep dan peranan amalan filantropi sepertimana ditekankan dalam agama Islam. Masyarakat terbuka untuk lebih memberi bagi tujuan kesejahteraan diri. Melalui tahap kefahaman yang tinggi terhadap amalan filantropi sedikit sebanyak membuktikan bahawa masyarakat cakna tentang amanah dan tanggungjawab yang perlu dititik beratkan agak hak dan keperluan masyarakat sentiasa terbela. Justeru itu, aspek filantropi akan terus dioptimumkan sepanjang krisis pandemik COVID-19 berlaku.

Amalan filantropi ini dapat dilihat melalui sumbangan orang ramai dalam pelbagai dana, tabung dan aktiviti-aktiviti kebajikan yang dianjurkan oleh badan-badan kerajaan atau bukan kerajaan (Nongovernmental Organisation, NGO). Misalnya, MyCARE di Johor berjaya mengumpul dana dari orang ramai sebanyak RM6,300, di mana dengan dana ini MyCARE Johor dapat menyumbangkan barangan keperluan asas kepada golongan sasar di selatan tanah air (Rosyahaida, 2020). Selain itu, terdapat juga individu yang secara sukarela menjahit pakaian pelindungan (Personal Protective Equipment atau PPE) untuk disalurkan kepada seluruh hospital di Malaysia Badan kerajaan juga seperti PETRONAS melalui Yayasan PETRONAS telah memberi sumbangan peralatan dan bekalan perubatan bernilai RM20 juta bagi membantu hospital dan petugas barisan hadapan penjagaan kesihatan (Mahani, 2020).

Selain itu, melalui tahap kefahaman terhadap amalan filantropi dalam kalangan masyarakat membuktikan bahawa tradisi dan amalan filantropi yang telah dipraktikkan sejak awal pemerintahan Islam masih relevan dan menjadi kesedaran tentang kepentingannya dalam kehidupan masyarakat pada hari ini. Tahap kefahaman merupakan asas pembentukan jati diri membina kembali persekitaran ekonomi yang mapan. Firman Allah SAW dalam surah Al-Hasyr ayat 7, bermaksud;
"Harta rampasan fai' yang Allah berikan kepada Rasul-Nya (Muhammad) daripada harta penduduk beberapa negeri ialah untuk Allah, Rasul, kaum kerabat (Rasul), anak-anak yatim dan orang miskin, serta ibnu sabil (orang yang bermusafir atau orang yang dalam perjalanan), agar harta itu tidak hanya beredar antara orang kaya dalam kalangan kamu".

Seterusnya, dapatan kajian juga menunjukkan sikap dan tingkah laku terhadap amalan filantropi telah membuktikan penglibatan masyarakat adalah positif dalam pendekatan menyediakan bantuan untuk 
menangani impak COVID-19. Masyarakat dilihat sentiasa bersedia dan rela untuk terlibat secara langsung serta bersama-sama memfokuskan kepada memenuhi keperluan dan kepentingan golongan yang terjejas dalam tempoh pandemik ini. Amalan filantropi sangat erat jalinannya dengan maqasid alsyariah untuk menjaga kesejahteraan bersama di mana ia merupakan mekanisme yang membentuk satu jaminan keselamatan sosial bagi mereka yang amat memerlukan, di samping membangunkan pertumbuhan sosio-ekonomi yang seimbang dan adil. Sikap dan tingkah laku terhadap amalan filantropi berdasarkan dapatan kajian yang diperoleh dapat dibuktikan apabila Pusat Pungutan Zakat (PPZ) berjaya mengumpulkan RM357, 011,562 hasil kutipan zakat sepanjang bulan Januari sehingga Jun 2020 (Sinar Harian, 2020).

Hasil statistik deskriptif ini juga menunjukkan bahawa tahap keprihatinan masyarakat sangat tinggi untuk menyumbang melalui zakat yang mana dana tersebut telah diagihkan kepada golongan yang layak menerimanya semasa COVID-19. Sepanjang lebih 1400 tahun (Razali, 2017), para dermawan Islam melalui elemen-elemen filantropi telah memberi sumbangan yang besar terhadap pembangunan sosio-ekonomi. Pembahagian bantuan dan sokongan telah diberikan termasuk memberi ruang dan peluang kepada individu mendapatkan kemudahan asas seperti makan, minum, tempat tinggal, modal, rawatan kesihatan serta pendidikan. Bahkan, amalan filantropi di Malaysia sewaktu bencana juga dibuat sejak dahulu lagi melalui pemberian zakat. Misalnya, sebanyak RM 3.8 juta zakat daripada Majlis Agama Islam Wilayah Persekutuan dibahagikan kepada sembilan buah negeri ketika banjir besar yang berlaku pada akhir tahun 2014 yang mengakibatkan kerosakan sebanyak RM2.85 bilion (Laporan Jabatan Mufti Wilayah Persekutuan, 2015). Selain itu, Majlis Agama Islam Kelantan juga turut memperuntukkan sebanyak RM32 juta wang zakat bagi membaik pulih kerosakan akibat banjir dan bantuan rumah baru sebanyak RM500 diberikan kepada mangsa banjir yang disenaraikan (Pejabat Tanah dan Jajahan Pasir Mas, 2015). Melalui amalan zakat yang diagih secara sistematik kepada individu yang memerlukan, ia juga sebagai satu gambaran kepada kesungguhan dan keikhlasan para dermawan dalam kalangan masyarakat yang menyumbang secara sukarela sekali gus menjadi salah satu faktor yang membawa kepada kehebatan tamadun Islam.

Penglibatan sikap dan tingkah laku positif terhadap amalan filantropi bukanlah sekadar menjalankan tanggungjawab semata-mata tetapi ia merupakan proses pembinaan masyarakat melalui keimanan, keikhlasan dan pada masa yang sama menjadi mekanisme untuk mengukuhkan iman. Malahan, ramai individu yang menganggur dan memerlukan dana untuk meneruskan kehidupan semasa dan pasca COVID-19 akan terbela hasil sumbangan yang diagihkan melalui institusi wakaf dan zakat yang telah dilantik. Filantropi atau kedermawanan tidak terbatas kepada amalan kebajikan yang bersifat sukarela semata-mata tetapi Islam turut menekankan instrumen kedermawanan yang berstatus wajib seperti zakat yang diberikan oleh umat Islam yang mampu dan cukup syaratnya kepada golongan yang berhak menerimanya. Bagi memastikan kesinambungan kesejahteraan hidup masyarakat, tahap kefahaman dan tingkah laku masyarakat terhadap amalan filantropi perlu dipertingkatkan dari semasa ke semasa untuk memastikan pengagihan sumber dan dana diteruskan hingga keadaan kembali pulih. Selain pihak berwajib, masyarakat perlu sentiasa memikirkan strategi untuk merancang dan meningkatkan penglibatan dan kefahaman secara menyeluruh dengan mengambil pendekatan filantropi sebagai alternatif untuk mengurangkan impak krisis COVID-19 terhadap masyarakat.

\section{Kesimpulan}

Secara keseluruhannya, amalan filantropi yang berlandaskan kepada rasa cinta dan kasih sesama manusia telah menjadi dorongan untuk setiap individu melakukan kebaikan. Amalan kedermawanan yang ditonjolkan oleh Rasulallah SAW berpandukan al-Quran telah menjadi contoh dan ikutan para ulama, pemikir Islam dan umat keseluruhannya. Garis panduan amalan filantropi yang komprehensif bermatlamatkan taqarrub dan qurba berjaya menghasilkan para dermawan yang baik, jujur, amanah, bertanggungjawab dan berperikemanusiaan seterusnya membawa kepada kemuncak dan kegemilangan pembangunan masyarakat yang dinamik dari pelbagai aspek merangkumi ekonomi, politik dan sosial.

Walau bagaimanapun konsep dan amalan filantropi Islam adalah berbeza dengan filantropi yang dipegang oleh masyarakat Barat kerana Islam bersandarkan rasa cinta kepada manusia, rasa 
tanggungjawab, amanah dan cinta untuk memenuhi perintah Rasulallah SAW dan Allah SWT. Sikap dan tingkah laku terhadap amalan filantropi Islam bertujuan memperoleh ganjaran pahala berlipat ganda dan memperoleh keredhaan dalam setiap apa yang dilakukan. Islam bukan sekadar berharap individu menjadi dermawan yang baik semata-mata tetapi turut menyemai rasa kasih sayang dalam diri masyarakat umum dengan membiasakan diri melakukan kebaikan yang mendatangkan manfaat bersama.

Krisis pandemik COVID-19 telah mengakibatkan gangguan ketidakseimbangan dalam kehidupan seharian masyarakat. Cabaran yang dihadapi pada saat ini amat berbeza dan sukar berbanding beberapa krisis yang pernah dialami sebelum ini misalnya krisis kewangan pada tahun 2008. Walau bagaimanapun, asas-asas filantropi telah mendorong masyarakat untuk memberi sumbangan dalam pelbagai bentuk sama ada wang ringgit, barang kemas, harta dan sebagainya selain terlibat dalam amal jariah lain seperti sedekah dan aktiviti sukarelawan. Kebanyakan negara membangun pada hari ini khususnya negara Islam masih lagi berusaha untuk membentuk satu sistem filantropi yang berstruktur dan berorganisasi. Filantropi Islam mempunyai potensi besar untuk diguna pakai demi kebaikan bersama. Namun, beberapa perkara seperti tahap kefahaman dan tingkah laku masyarakat terhadap amalan filantropi perlu diperhalusi dari semasa ke semasa.

\section{Penghargaan}

Sekalung penghargaan ditujukan kepada Pihak Universiti Sains Islam Malaysia atas pembiayaan geran penyelidikan yang bertajuk "Tahap Kefahaman Filantropi Islam (Kedermawanan) Dalam Kalangan Masyarakat Untuk Menghadapi Pasca COVID-19” (PPP1/COVID19_0120/FEM/05100/13120.

\section{Rujukan}

\section{Al-Quran al-Karim}

Abdul Hadi Awang. (2008). Beriman kepada qadak dan qadar. Batu Caves. Selangor.Ots Islamika.

Abdul Hasbi, Z. (2018). Aplikasi wakaf kontemporari dalam konteks filantrofi Islam: Kajian persepsi masyarakat di Indonesia dan Malaysia. Universiti Kebangsaan Malaysia.

Abdiansyah, L. (2015). Filantrofi islam sebagai instrumen keadilan ekonomi. Jurnal Prespektif Darussalam, 1(2): 154-171

Abdul Halim, S. (2007). Dana wakaf untuk pendidikan: Satu tinjauan awal. Jurnal Pengurusan JAWHAR, 1(2).

Abdullah Alqari, M. Z., Wan Mohd, W. C, Engku Muhammad, T. E. A., \& Syed Mohd Azmi, S. A. R. (2018). Potensi filantropi islam dalam Institusi Pemulihan Dadah. Asian People Journal (APJ), 1(2): 125-134.

Al-Sharanbasiyy, Ramadan Aliyy al-Sayyid. (2002). Ahkam al-Mirath Bayna al-Sharicah Wa alQanun. al-Iskandariyyah: Mansha'at al-Macarif.

Alterman, Jon B., \& Hunter, S. (2004). The ideas of philantrophy in Muslim contexts. USAID (United States Agency International Development). Washington: The Center for Strategic and International Studies.

Anwar, M. A. (2014). Undang-undang pentadbiran Zakat pada zaman awal Islam. International Conference on Masjid, Zakat and Waqf (IMAF 2014), 1-2 December, Kuala Lumpur: Malaysia.

Aris, P. P., \& Muchlis, Y. (2018). A Review on Islamic philantrohy literature between 2008 to 2018. Jurnal Al-Muzara'ah, 6(2): 129-138.

Bakr, M.A. (2001). Islam, Civil Society, and Ethnic Relations in Malaysiain N. Mitsuo, S. Siddiquue, and O.F.Bajunid, eds., Islam and Civil Society in Southeast Asia (Singapore: Institute of Southeast Asian Studies).

Bekkers, R \& Wiepking, P. (2011). A Literature review of empirical studies of philanthropy: Eight mechanisms that drive charitable giving. Nonprofit and Voluntary Sector Quarterly, 40(5): 924 73.

Sinar Harian. (2020, 16 September, Isnin). Baitulmal MAIWP permudahkanlah bantuan zakat, kata Zulkifli. Sinar Harian, Nasional. Retrieved from 
https://www.sinarharian.com.my/article/93262/BERITA/Nasional/Baitulmal-MAIWPpermudahkanlah-bantuan-zakat-kata-Zulkifli

Berita Harian Online (2020, 3 Julai, Jumaat. COVID 19: Angka kematian dunia hamper 518,000. Berita Harian Online, Dunia. Retrieved from https://www.bharian.com.my/dunia/eropah/2020/07/706738/covid-19-angka-kematian-duniahampiri-518000

Bilal, A. M. (2016). Philanthropy in practice: Role of zakat in the realization of justice and economic growth. International Journal of Zakat, 1(1): 64-77.

Cucinotta, D \& Vanelli. (2020). WHO declares Covid 19 a Pandemic. Acta Biomed, 91(1), 157-160.

Cogswell, E. (2002). Private philanthropy in multiethnic Malaysia. Macalester International,12(1), $105-121$.

Cresswell, J.W. (2012). Educational research: Planning, conduct and evaluating quantitative and qualitative research. 4th ed. Bonston: Pearson.

Fauzi al-Maburok \& Ahmad Buchori, M. (2020). Kesalehan Sosial Melalui Pendidikan Philantropi Islam. Journal of Islamic Education: Basic and Applied Research, 1(1): 1-15.

Fishbein, M., \& Ajzen, I. (1975). Belief, attitude, intention and behaviour: An introduction to theory and research. Reading: M.A Addison-Wesley.

Hadil, A., Fatemah, B \& Reem, A. (2020). An Analytical study on awareness, attitude and practicing during the COVID-19 pandemic in Riyadh, Saudi Arabia Journal of Infection and Public Helath:1-7.

Icek Ajzen. (1991). The Theory of Planned Behavior. Organizational Behaviour and Human Decision Processes 50, 179-211.

Ismail, A. G., Zaenal, M. H., \& Shafiai, H. (2013). Philanthrophy in Islam : A promise to welfare economics system. Proceedings of World Universities' Islamic Philanthropic 2013, 1-2.

Jabatan Perangkaan Malaysia. (2020). Sekteriat dan Jawatankuasa Khas DOSM menangani COVID19: Statistik \& Info Media (BDA), 54:1-49.

Jusuf, C. (2007). Filantropi modern untuk pembangunan sosial. Jurnal Penelitian Dan Pengembangan Kesejahteraan Sosial, 12(1), 74-84.

Joseph. F. H \& Babbie F, H. (1997). Exploring social issues using spss for windows. California: Pine Forge Progress.

Josie M, F. \& Abdul Rahim, I. (2002). A giving society?: The State of Philantrophy in Malaysia. Penang: Universiti Sains Malaysia.

Kamaruddin, M. I. H., \& Ramli, N. M. (2015). Enhancing financial accountability of Islamic philanthropic organizations through financial disclosure. Online Journal of Research in Islamic Studies, 1(2):129-42.

Kamus Dewan Edisi Keempat. (2010). Dewan Bahasa dan Pustaka.

Kementerian Kesihatan Malaysia. (2020). Laporan Harian Kes COVID-19. Capaian pada 10 Oktober 2020 dari http://covid-19.moh.gov.my/

Klein, Kim. (2001). Fundraising for sosial change. $4^{\text {th }}$ Edition. Oakland California: Chardon Press.

Lilly Family School of Philanthropy. (2013). The Million Dollar Donors Report 2013. coutts.com/donorsreport

Liza Mokhtar \& Ridaudin Daud. (2020). 21 Mac Sabtu. Pakej selamatkan ekonomi angkara COVID19. Sinar Harian. Retrived from https://www.sinarharian.com.my/article/74759/BERITA/Nasional/Pakej-selamatkan-ekonomiangkara-Covid-19

Lwin, Michael, Ian Phau \& Aaron Lim. (2013). Charitable Donations: Empirical Evidence from Brunei. Asia-Pacific Journal of Business Administration, 5(3); 215-233.

Madhu, S. Mohanty. (2011). Effects of Charity on Social Welfare: A theoretical analysis. Sociology Mind, 1(2): 33-35.

Mahani Ishak (Mei 15, 2020).PETRONAS komited hulur bantuan demi kesejahteraan masyarakat. Berita Harian Online. Dicapai pada 1 Oktober 2020 dari https://www.bharian.com.my/berita/nasional/2020/05/688955/petronas-komited-hulur-bantuandemi-kesejahteraan-masyarakat

Merriam-Webster. Merriam-Webster Online Dictionary Online. (2008).

McCully, George (2008). Philanthropy reconsidered : Private initiatives public good quality of life. Bloomington. AuthorHouse. 
Malaysian Journal of Social Sciences and Humanities (MJSSH), Volume 5, Issue 12, (page 1 - 15), 2020

DOI: https://doi.org/10.47405/mjssh.v5i12.591

Mohd Faez Mohd Shah \& Noor Naemah Abdul Rahman. (2014). Kepentingan kaedah penyelidikan moden dalam fatwa semasa. Jurnal Pengurusan dan Penyelidikan Fatwa. 4. Nilai: Penerbit Universiti Sains Islam Malaysia.

Mohd Faisal, M. Y., Mohd Faiz, M. Y., Mazlin, H. H., Nurhanani, R. (2011). Cash \& Infaq: A proposed E-Philantrophy in Malaysia. Jurnal Kemanusiaan, 22, 1-10.

Mohd Farhan, A., Mohd Ali, M. D, Mahfuzah, M. Z, Rohaya, S \& Azizah M. S. (2018). The National Model of Philantrophy towards the global philantrophic practices. International Journal of Academic Research in Business \& Social Sciences, 8(11), 791-799.

Mohd Nahar. (2017). Kejayaan Konsep Filantropi Barat Satu Panduan kepada Pengurusan Wakaf. Seminar filantrofii dan derma bakti Islam. Pendekatan Korporat dalam Konsep Wakaf.

Mohd Zahir, Z., Roziah, O \& Mohd Fuazi, K. (2015). Implementasi dasar sosial dan impak kepada komuniti: Kajian Perbandingan di Malaysia dan Indonesia. International Journal of the Malay World and Civilisation (Iman), 3(3), 29-40.

Mufti Wilayah Persekutuan. (2015). Irsyad Fatwa Ke-14 : Hukum Memberi Zakat Kepada Mangsa Bencana Alam Seperti Banjir Dan Lain-Lain. Capaian pada 5 Oktober 2020 dari http://www.muftiwp.gov.my.

Muhammmad Yusri, M. (2020, 22 April Rabu). Covid-19: Bayar Zakat Fitrah dalam talian. Berita Harian Online, COVID-19. Retrieved from https://www.bharian.com.my/berita/nasional/2020/04/680266/covid-19-bayar-zakat-fitrah-dalam$\underline{\text { talian }}$

National Philanthropic Trust. (2015). Donor-Advised Fund Report 2015. http://www.nptrust.org/dafreport/

Qurratul Uyun. 2015. Zakat, infaq, shadaqah, dan wakaf sebagai konfigurasi filantrofi Islam, Islamuna, 2(2).

Payton, R. L (1988). Philanthropy: Voluntary action for the public good. New York: American Council on Education.

Pejabat Tanah dan Jajahan Pasir Mas. (2015). Penyerahan Kunci Rumah Agihan Zakat (MAIK). Capaian pada 6 Oktober 2020 dari http://ptipm.kelantan.gov.my/index.php/my/penerbitan/beritaterkini/12-arkib-berita/93-penyerahan-kunci-rumah-agihan-zakat-maik-dan-penyampaian-oneoff-zakat-maik-kepada-mangsa-banjir-dan-asnaf-miskin-di-jajahan-pasir-mas-bagi-tahun-2015.

Prihatini, F. Et. Al. (2005). Hukum Islam zakat dan waqaf. Jakarta. Papas Sinar Mentari \& Badan Penerbit Fakultas Hukum Universitas.

Pryce, H. \& Hall, A., Hill, R, G. (2015). The role of volunteer support in the community for adults with the hearing loss and hearing aids. Patient Education and Counselling, 98(8): 954-960.

Razali Othman. (2017). Konsep Philantropi dalam Sudut Pandangan Islam. Seminar Filantrofi Derma-Bakti Islam: Pendekatan Korporat Dalam Konteks Wakaf. Kuala Lumpur: Institut Kefahaman Malaysia.

René Bekkers and Pamala Wiepking. (2011). A Literature Review of Empirical Studies of Philanthropy: Eight Mechanisms That Drive Charitable Giving. Nonprofit and Voluntary Sector Quarterly, 40(5), 924-973.

Robert, H. B. (1988). American Philanthropy. Chicago: University of Chicago Press.

Rosyahaida Abdullah (Mac 28, 2020). MyCare Bantu Keluarga Terjejas Covid-19. Harian Metro. $\begin{array}{lllll}\text { Dicapai } & \text { pada } & 10 & \text { Oktober } & 2020 \\ \end{array}$ https://www.hmetro.com.my/mutakhir/2020/03/559589/mycare-bantu-keluarga-terjejas-covid-19.

Salamon, L. M., Anheier, H. K. (1992). In search of the non-profit sector II: The problem of Classication. Voluntas, 3(3), 267-309.

Salwa Amirah, A., Joni Tamkin, B., Mohamad Taqiudin, M. \& Fidlizan, M. (2017). The scenario of giving to beggars: A behavioral analysis among Malaysian. Labuan e-Journal of Muamalat and Society, 11, 39-50.

Samiul Hasan. (2004). Islamic Philantrophy, Social Justice and Development: Modern Challenge \& Responses. International Society for Third-Sector Research Biennial Conference. Ryerson University: Canada. July 11-14 July.

Sekaran, U. \& Bougie, R. (2003). Research \& Method for Business: A skill Buiding Approach. New York John Willey \& Son. 
DOI: https://doi.org/10.47405/mjssh.v5i12.591

Siti Hasnah, H., Tajul Ariffin, M. Noor,. M \& Ramayah, T. (2018). Antecedents of trust towards the attitudes of charitable organization in monetary philantrophic donation among generation-Y. Asian Academy of Management Journal, 23(1), 53-78.

Skarmeas, D. \& Shabbir, H.A. (2011). Relationship quality and giving behaviour in the UK fundraising sector exploring the antecedent roles of religiosity. European Journal of Marketing, 45(5), 720-38.

Tamin, I. H. (2011). Peranan filantropi dalam pengentasan kemiskinan di dalam komunitas lokal. Jurnal Sosiologi Islam, 1(1), 35-58.

Tohari, Hajriyanto Y, Muhammadiyah. (2017). Sebagai Gerakan Filantropi: Perspektif Historis dan Sosiologis. Baitul Arqam Fakultas Ekonomi dan Bisnis UHAMKA.

Wan MohdYusof, W. C, Engku Muhammad Tajuddin, E. Ali, Syed Mohd Azmi Syed, A.R, Abdullah Alqari, M. Z. (2018). Filantrofi: Satu sorotan dari sudut hukum taklifi. Asian People Journal, $1(1), 12-27$.

Zain, S. M., Mahmood N. A., Basri, N. E. A., Zawawi. M, Mamat, L. F. \& Saad N, F, M. (2014). Ekorelawan Kejuruteraan Dan Pendidikan Kelestarian Kongress Pengajaran Dan Pembelajaran:UKM Februari 11-12, 1-12. 